\title{
Stability of electrolyzed water: from the perspective of food industry
}

\author{
${ }^{1}$ Khalid, N.I., ${ }^{1}$ Sulaiman, N.S., ${ }^{1,2 *}$ Ab Aziz, N., ${ }^{1}$ Taip, F.S., ${ }^{3}$ Sobri, S. and \\ ${ }^{4}$ Nor-Khaizura, M.A.R. \\ ${ }^{I}$ Department of Process and Food Engineering, Faculty of Engineering, Universiti Putra Malaysia, 43400 \\ Serdang, Selangor, Malaysia. \\ ${ }^{2}$ Halal Products Research Institute, University Putra Malaysia, 43300 UPM Serdang, Selangor, Malaysia. \\ ${ }^{3}$ Department of Chemical and Environmental Engineering, Faculty of Engineering, Universiti Putra \\ Malaysia, 43400 Serdang, Selangor Darul Ehsan, Malaysia \\ ${ }^{4}$ Department of Food Science, Faculty of Food Science and Technology, Universiti Putra Malaysia, 43400, \\ UPM Serdang, Selangor, Malaysia.
}

\begin{abstract}
Article history:
Received: 18 April 2020

Received in revised form: 23

July 2020

Accepted: 11 October 2020

Available Online: 3 January 2021
\end{abstract}

\section{Keywords:}

Disinfection,

Electrochemically activated

water,

Electrolysis,

Novel disinfectants,

Sanitation,

Sustainable cleaning

DOI:

https://doi.org/10.26656/fr.2017.5(S1).027

\begin{abstract}
Green cleaner and disinfectant can provide a better environment and they can reduce cleaning cost by eliminating the cost of harsh cleaning chemicals, minimizing cleaning chemicals storage space, reducing cost for wastewater treatment and reducing logistics cost for chemical supply. This study explored the personal view of Small and Medium Enterprises (SMEs) top to bottom workers towards the challenges during cleaning and disinfection process and their readiness in accepting a green cleaner and disinfectant. In this work, the advantages and disadvantages of electrolyzed water (EW) as green cleaner and disinfectant were discussed. A lab-scale batch ion-exchange membrane electrolysis unit was used to produce acidic electrolyzed water (AcEW) and alkaline electrolyzed water (AlEW). The stability of AcEW and AlEW was also studied based on its physical changes $(\mathrm{pH}$, oxidative-reduction potential (ORP), chlorine content and hydrogen peroxide content) in 7 days of storage, whereby measurements were taken daily. The $\mathrm{pH}$ maintained for both AcEW and AlEW during the 7 days of storage. The ORP maintained at plateau for the first 5 days of AcEW storage. After 5 days, AcEW showed a decreasing trend. While ORP for AlEW increases drastically between day 1 and 2. Then, the ORP reaches a plateau after three days. The amount of free chlorine, total chlorine and hydrogen peroxide content was $10 \mathrm{mg} / \mathrm{L}$, respectively, on the day of production. However, all the properties decreased gradually and there were no chlorine and hydrogen peroxide detected on the 7th day. The results from this study can be used as a guideline to store the EW and to understand the stability of the EW, which can benefit the SME food manufacturers.
\end{abstract}

\section{Introduction}

Selection of suitable cleaning detergents and disinfection (or also known as sanitisation in the USA) for SMEs can be costly and complex. Considering SMEs financial aspect, they are facing difficulties in finding a balance between the cleaning detergent cost and its performance. Food-grade cleaning detergents are easy to rinse and poses less harm to food contact surfaces and food products. However, these types of detergents can be expensive and can be a burden to SME food manufacturers. Generally, there are three types of cleaning detergents for the food industry: 1) pure chemicals, 2) formulated detergents and 3) pure chemicals with additives. The main components of all chemicals are always an alkali or an acid. The selection of the main components is depending on the nature of food soil in the processing system. Then, after the cleaning process, the food contact surfaces are disinfected to inactivate microorganism that is harmful to humans. Disinfection of food contact surfaces can be done with moist heat at a range of 90 to $95^{\circ} \mathrm{C}$ (Tetra Pak International S.A., 2015), with hot water of $75^{\circ} \mathrm{C}$ (Heinz and Hautzinger, 2007; Watkinson, 2008; Hui, 2012; Khalid et al., 2019) or with chemicals (Khalid et al., 2016). Food manufacturers commonly use two types of 
cleaning detergents in order to achieve cleanliness. Sodium hydroxide is commonly used as an alkalinebased detergent to remove the carbohydrate-based fouling deposit for cleaning, and disinfectant (e.g., sodium hypochlorite) is used for disinfection (Walton, 2008). Alkaline-based cleaning chemical is commonly used for cleaning food-contact surfaces. Acid cleaning cycle (e.g., acetic acid) is added onto food contact surfaces that process food (commonly dairy products) that contain mineral such as calcium, phosphorous, and riboflavin (Walton, 2008).

Even though there are formulated cleaning detergents which can cater function of multiple cleaning and disinfection chemicals, there is still a need to find a green cleaner as we are becoming increasingly health and eco-conscious. Thus, the demand for sustainable initiatives also grows. One of the green cleaner available today is the electrolyzed water $(\mathrm{EW})$. $\mathrm{EW}$ is one of the green alternatives solution for both cleaning and disinfection chemicals whereby EW can be produced through the electrolysis process of salt solution only. As the electrolysis cell with an ion-selective membrane is subjected to current, two types of solution are produced. Acidic electrolyzed water (AcEW) is produced at anode. AcEW contains hydrogen peroxide, $\mathrm{H}_{2} \mathrm{O}_{2}$ (Rico et al., 2007; Stanga, 2010), ozone gas, $\mathrm{O}_{3}$ (Guzel-Seydim et al., 2004; Stanga, 2010; Meireles et al., 2016), hypochlorous acid, $\mathrm{HOCl}$, hyphochloric acid, $\mathrm{HCl}$ (Meireles et al., 2016) and hypochlorite ion, $\mathrm{ClO}^{-}$(Meireles et al., 2016). All of these components make AcEW to be a powerful sanitiser in disinfecting many types of foodborne pathogens such as Salmonella (Venkitanarayanan et al., 1999; Fabrizio and Cutter, 2004), Escherichia coli (Venkitanarayanan et al., 1999; Ozer and Demirci, 2006) and Listeria monocytogenes (Venkitanarayanan et al., 1999; Ozer and Demirci, 2006). Whereas alkaline electrolyzed water (AlEW) contains sodium hydroxide; a grease-cutting cleaner produced at cathode. In contact with $\mathrm{NaOH}$, fouling deposit will swell and assist the dirt removal (Khalid et al., 2016).

Most of the SME factories have small factory areas which allow them to have limited storage area. Bulk purchasing of cleaning detergents can reduce the total cleaning cost, but the limited storage area becomes a hindrance. Moreover, SMEs only use a small amount of cleaning detergents which leads to more cleaning detergents becoming expired. Treatment or disposal of the expired chemicals will only contribute to a negative effect on the environment and increase the operating cost. EW is seen as a potential in solving the storage problem as it can be produced on-site and does not need any storage area (Khalid, Ab Aziz, Thani et al., 2020).
The research is aimed to identify the potential of EW as green cleaner and disinfectant in the food industry SMEs. The effect of storage duration on chemical properties of acidic electrolyzed water (AcEW) and alkaline electrolyzed water (AlEW) was also studied. The results obtained from this work can be used as a guideline for SMEs to apply and store the EW reasonably.

\section{Materials and methods}

2.1 Identifying the potential of $E W$ as green cleaner in the food industry

Face to face unconstructed interviews (impromptu) were conducted in an SME meat processing factory (factory X) in Selangor, Malaysia. The factory produced different types of burgers (beef, lamb and chicken). The manufacturing process of the factory includes weighing, flaking, mincing, pre-mixing, mixing, burger forming, blast freezing, packing and frozen storage (Khalid, Saulaiman, Nasiruddin et al., 2019). Questions related to cleaning and sanitation process were asked during the interviews. The interview was not transcribed. However, notes were taken during the interview. The purpose of this interview is to understand the difficulties of SME food manufacturer in implementing good cleaning practices. The questions included the selection of cleaning and disinfection detergents, storage for cleaning apparatus and chemical storage conditions. A short visit during cleaning was also conducted. Moreover, the potential application of EW in the food industry for replacing commercial cleaning chemicals was also asked during the interview. Several workers related to cleaning and sanitation process were interviewed with 1) production manager, 2) quality assurance/quality control (QA/QC) manager, 3) production worker 1, and 4) production worker 2 .

\subsection{Preparation of electrolyzed water}

A laboratory-scale batch electrolysis unit was used to generate acidic electrolyzed water (AcEW) and alkaline electrolyzed water (AlEW). The electrolysis unit (Figure 1) was designed and constructed at the Department of Process and Food Engineering, Faculty of Engineering, Universiti Putra Malaysia, Malaysia. Both the cathode and anode chambers were made of acrylic glass that allowed visual observation during the electrolysis process. The chamber can be filled with electrolyte up to 6 litres (3 litres per chamber). The chambers are separated by a polyester UF membrane which allowed ion exchange during the electrolysis process. DC power supply (PSW, $0-30 \mathrm{~V}, 0-36 \mathrm{~A}, \mathrm{GW}$ Instek, Taiwan) is used to control the voltage. In this work, $3.4 \mathrm{~L}$ diluted sodium chloride solution (R\&M Chemicals, United 
Kingdom) was poured into the electrolysis unit $(1.7 \mathrm{~L}$ salt solution in each chamber). Both the cathode and anode which were made of stainless steel 316 were installed and the chamber was closed. Then, current approximately in the range of 2.0 to $2.2 \mathrm{~A}$ was subjected to the electrolysis unit. At the end of the electrolysis process, AcEW and AlEW were collected at anode and cathode chambers, respectively.
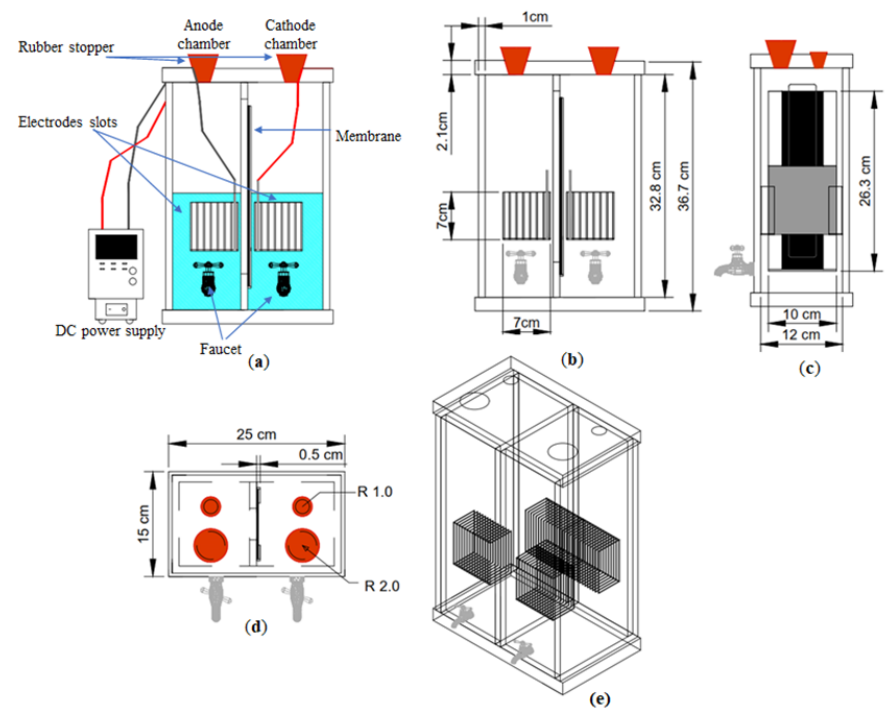

Figure 1. Schematic diagram of the laboratory-scale batch electrolysis unit: a) front-side view (complete set-up), b) front -side view c) right view, d) top-side view and e) perspective view.

\subsection{Stability of electrolyzed water}

After electrolysis, the changes towards the chemical properties ( $\mathrm{pH}$, oxidation-reduction potential (ORP), free chlorine, total chlorine and hydrogen peroxide content) of EW were tested. Then, $100 \mathrm{~mL}$ of AcEW and $100 \mathrm{~mL}$ of AlEW were stored in a dark brown tightly-screwed closed bottle at room temperature $\left(25-30^{\circ} \mathrm{C}\right)$. The amount of $\mathrm{pH}, \mathrm{ORP}$, free chlorine, total chlorine and hydrogen peroxide content of EW were measured at every 24 hrs for 7 days according to previous researchers (Hsu and Kao, 2004; Cui, et al., 2009; Khalid et al., 2018). For every $24 \mathrm{hrs}$, the bottles were opened for approximately 5 mins for analytical measurements. The experiment was repeated for 3 times and each repetition was carried out at different week.

\subsection{Analytical measurement of electrolyzed water}

Free and total chlorine test strips $0-10 \mathrm{mg} / \mathrm{L}$ (Hach, Unites State) were used to estimate the free chlorine and total chlorine content in electrolyzed water. The hydrogen peroxide test strip $0-10 \mathrm{mg} / \mathrm{L}$ (MachereyNagel, Germany) was used to estimate the content of hydrogen peroxide. The $\mathrm{pH}$ was measured using a portable $\mathrm{pH} / \mathrm{mV} / \mathrm{ISE}$ meter equipped with $\mathrm{pH}$ electrode (Fisher Scientific, USA). Oxidation-reduction potential (ORP) was measured using a portable $\mathrm{pH} / \mathrm{mV} / \mathrm{ISE}$ meter equipped with redox electrode (Boeco, Germany). Table 1 shows the reactions involved during the electrolysis process (Al-Haq et al., 2005; Rahman et al., 2016). As shown in Table 1, chlorine and hydrogen peroxide are only generated at the anode chamber which contributes to the AcEW's properties. Thus, the $\mathrm{pH}$, ORP, free chlorine, total chlorine and hydrogen peroxide are measured for AcEW. Whereas, only $\mathrm{pH}$ and ORP were measured for the AlEW.

\section{Results and discussion}

\subsection{Background of the impromptu interview}

Factory $\mathrm{x}$, a meat processing factory was used in this work. Factory $\mathrm{x}$ was chosen as the case study due to the prior research conducted by (Hasnan et al., 2019). Hasnan et al. (2019) proposed a spine plant layout design for the factory $\mathrm{x}$. The suggested spine plant layout that was proposed by Hasnan et al., (2019) was expected to improve the food hygiene and reduce the travelled distances inside this small-scale meat processing factory. After the implementation of the new plant layout, a short visit was conducted. The improved plant layout itself solely cannot improve the hygienic environment of the factory. Thus, during the visit's meeting, the topic regarding improving the cleaning and sanitation of factory $\mathrm{x}$ was discussed. The group meeting was attended by the production manager and the QA/QC manager. They explained the cleaning and sanitation difficulties that they were facing. The meeting took about one and a half hours. Notes were taken during the meeting. After the meeting, two production workers were interviewed individually. The individual interview took about 30 mins each. During the interview and discussion, notes were taken. The finding was determined based on the notes taken and the observation

Table 1. Reactions involve during the electrolysis process (Al-Haq et al., 2005; Rahman et al., 2016)

\begin{tabular}{|c|c|}
\hline Anode & $\begin{array}{r}\text { Cathode } \\
\end{array}$ \\
\hline $2 \mathrm{NaCl}=\mathrm{Cl}_{2}(\mathrm{~g})+2 \mathrm{e}^{-}+2 \mathrm{Na}^{+}$ & $2 \mathrm{H}_{2} \mathrm{O}_{2}(\mathrm{l})+2 \mathrm{e}^{-}=2 \mathrm{OH}^{-}+\mathrm{H}_{2}(\mathrm{~g})$ \\
\hline $2 \mathrm{H}_{2} \mathrm{O}(\mathrm{l})=4 \mathrm{H}^{+}(\mathrm{aq})+\mathrm{O}_{2}(\mathrm{~g})+4 \mathrm{e}^{-}$ & $2 \mathrm{NaCl}+2 \mathrm{OH}^{-}=2 \mathrm{NaOH}+\mathrm{Cl}^{-}$ \\
\hline $\mathrm{Cl}_{2}+\mathrm{H}_{2} \mathrm{O}(\mathrm{l})=\mathrm{HCl}+\mathrm{HOCl}$ & \\
\hline $\mathrm{H}_{2} \mathrm{O}=\mathrm{H}^{+}+\cdot \mathrm{OH}+\mathrm{e}^{-}$ & \\
\hline$\cdot \mathrm{OH}+\cdot \mathrm{OH}=\mathrm{H}_{2} \mathrm{O}_{2}$ & \\
\hline - $\quad$ Acidic electrolyzed water is obtained & - Alkaline electrolyzed water is obtained \\
\hline - Chlorine species $(\mathrm{HCl}, \mathrm{HOCl})$ are generated & - $\quad$ Sodium hydroxide $(\mathrm{NaOH})$ is generated \\
\hline - Hydrogen peroxide is generated $\left(\mathrm{H}_{2} \mathrm{O}_{2}\right)$ & \\
\hline
\end{tabular}


during the visit. The themes and similarity of the notes were analysed.

\subsection{Challenges of cleaning from Small and Medium Enterprise (SME) perspectives}

Based on the group discussion (meeting) and individual reflection of production workers, four major problems were identified which are: 1) difficulty in selecting the cleaning and disinfection chemical, 2) limited knowledge in cleaning and disinfection process, 3 ) budget constraints and 4) limited storage area. First, in implementing a cleaning program, the selection of good cleaning detergents is very difficult for SMEs. They claim that food-grade detergents are expensive and eventually can become a burden. Thus, they tend to purchase a cheap cleaning detergent without any proper material safety data sheet (MSDS).

Second, they believe visual cleanliness is the only indicator which can validate their cleaning programs. Most of the SMEs are unaware of cleaning indicators for food industries which are physical (visual, touch and smell), microbiological and chemical cleanliness (Khalid et al., 2019). These indicators are also known as cleaning target for some food industries. These three cleanliness indicators are important to ensure the products are safe and do not contaminate microbiologically, physically and chemically (Walton, 2008). Moreover, a clean environment contributes to a more healthy and safe working environment for workers. Maintaining cleanliness in food manufacturing premise is of the utmost importance to create a safe, enjoyable, comfortable, and stress-free environment for workers in the food industry (Khalid et al., 2019).

Third, food SMEs have a limited budget which constraints them in implementing a good cleaning process. They tend to skip the costly cleaning process such as hot water rinsing. Hot water rinsing is used to melt the invisible fat layer which is commonly found in meat processing area (Khalid and Ab Aziz, 2019). SMEs try to avoid boiler utilization as it will increase the operating and maintenance cost (Khalid and Ab Aziz, 2019). This hot water rinsing increases the cleaning performance and also capable to act as disinfectant in inactivating foodborne pathogens (Heinz and Hautzinger, 2007; Watkinson, 2008; Hui, 2012; Khalid et al., 2019). An expensive disinfectant chemical can be replaced with this hot water rinsing process at $75^{\circ} \mathrm{C}$ (Heinz and Hautzinger, 2007; Watkinson, 2008; Hui, 2012; Khalid et al., 2019). This will reduce the operating cost. However, most of food SMEs do not know about this and continue to purchase expensive disinfectant chemicals. Then, when they were asked if they are willing to accept other cleaning chemical solution, they stated that they are open for the suggestion as long as the alternative cleaning solution is cheap and effective. Thus, EW, which is environmentally friendly and cheap can be accepted in SME factories.

Last but not least is the limited storage area. Bulk purchasing of cleaning chemicals can reduce the total cleaning chemicals cost. However, the storage area of SMEs is quite small. Most of the SME factories were set -up in a small and limited factories area. Thus, they have small chemical storage area which they have to store all unused (unopened bottles) chemicals, used chemicals, expired chemicals and cleaning apparatus (brushes, sweep, sponge etc.). Disposal of expired chemicals can be costly. Thus, they eventually decided to store the expired cleaning chemicals. EW which can be generated on-site does not need big space for storage and does not require further wastewater treatment. These are the key criteria which enhance the acceptance of EW in SME for cleaning and sanitation.

\subsection{Electrolyzed water as an affordable and green cleaner}

Electrolyzed water is claimable as a green and cheap cleaner with high potential as detergents for both cleaning and disinfection (Al-Haq et al., 2005; Rahman et al., 2016). Based on the interviews with SMEs, they are willing to accept this technology as the cost using EW is low because the only operating expenses are water, salts, and electricity in order to run the electrolyzing unit (Al-Haq et al., 2005; Rahman et al., 2016). However, the cost for initial capital investment to purchase the EW generator is not considered when calculating the cost. To date, there is no report made on the cost advantages regarding the usage of electrolyzed water in food industries. The actual cost advantage needs to be determined (Dev et al., 2014). The actual cost should consider the price of the initial purchase of EW generator, the shelf life of the EW generator, shelf life of electrode's materials (material for cathode and anode for electrolysis) and the membrane's shelf life. There are two main corrosive components in electrolyzed water which are salt and chlorine (Khalid, Sulaiman, Ab Aziz et al., 2020). Corrosion will reduce the electrode's material performance by reducing the current flow (Hsu et al., 2015, Khalid, Sulaiman, Ab Aziz et al., 2020). Eventually, the brown precipitate formed due to corrosion can attach to the membrane and eventually limiting the ion-exchange process (Khalid, Sulaiman, Ab Aziz et al., 2020). Frequent replacement of electrodes and membrane is needed. Therefore, future analysis may include short- and long-term cost analyses.

Alkaline electrolyzed water (AlEW) contains sodium hydroxide (Table 1); a grease-cutting cleaner which is 
able to remove oil, grease and fat. Detergency test using AlEW shows that it is able to eliminate $100 \%$ of the animal and vegetable oil formed on the steel's surface effectively (Shirota and Isaka, 2001). Since the properties of the AlEW are not affected by the heat effect, cleaning using AlEW at a higher temperature will contribute to higher cleaning efficiency (Dev et al., 2014). AlEW is also able to remove protein-based soil. For milking system that used cleaning-in-place (CIP) program for cleaning, AlEW has proven its potential to replace the sodium hydroxide $(\mathrm{NaOH})(\mathrm{Dev}$ et al., 2014; Wang et al., 2016). Whereas, acidic electrolysed water (AcEW) can be used to replace acidic-based detergent (Dev et al., 2014; Wang et al., 2016). Dev et al. (2014) and Wang et al. (2016) applied AcEW during cleaningin-place (CIP) process to clean the milking system as fouling deposit consists of some minerals. Their experimental works show that AcEW can replace the acid-based detergent and the sanitiser for CIP process of the milking system.

\subsection{Electrolyzed water as environmentally friendly cleaning medium}

Utilizing EW during cleaning is better for the environment, worker's safety and food safety as EW is less toxic than petroleum-based cleaning chemical (Colangelo et al., 2015; Gil et al., 2015; Rood et al., 2018). Food manufacturer acceptance of $\mathrm{EW}$ as cleaning medium, however, will likely depend on how well they can overcome the stigma that $\mathrm{EW}$ can cause equipment surface corrosion. Cleaning food equipment directly with salt solution can damage and reduce the shelf life of the equipment. This is one of the worries raised from SMEs when EW was suggested as an alternative green cleaner (Khalid, Ab Aziz, Thani et al., 2020). However, Ayebah and Hung (2005) reported that EW is less corrosive to stainless steel. Carbon steel, copper, aluminium and stainless steel had a fair, good and outstanding corrosion resistance in EW, respectively. Ayebah and Hung (2005) also indicated that AcEW water did not have any adverse effect on stainless steel. Stainless steel is the safest and suitable material for food contact surface manufacturing. Stainless steel shows an outstanding corrosion resistance in EW (Khalid, Sulaiman, Ab Aziz et al., 2020). Rinsing is a very important step in protecting the shelf life of the equipment material to avoid corrosion and to remove the chemical residue. After disinfection, washing the food equipment with sterile water can completely avoid metal corrosion (Ayebah and Hung, 2005). The effectiveness of rinsing can be measured by monitoring the conductivity (Stanga 2010). Conductivity is a measure of the concentration of the dissolved mineral in water (Etienne, 2006; Stanga, 2010). Moreover, EW reverts back to the original state when in contact with organic matter or if it is diluted by tap water, osmosis water or distilled water (Hati et al., 2012), thus reducing cost for wastewater treatment.

\subsection{Storage of acidic electrolyzed water}

Figure 2 shows properties ( $\mathrm{pH}, \mathrm{ORP}$, free chlorine, total chlorine and hydrogen peroxide) of AcEW during the 7 days of storage. There were two main factors which can reduce the chemical properties of EW which are exposed to the atmosphere and long duration of storage (Hsu and Kao, 2004; Khalid et al., 2018). In this work, seven days of storage was set as storage time assuming the food industries generate EW (using an EW generator) once a week for weekly consumption. From the SMEs perspective, daily usage of EW generator might be costly as it requires electrical energy to operate. Moreover, the weekly operation of the EW generator will be more convenient for the workers. Moreover, the common design of EW generator has a storage tank for EW. During the sanitation process, the tank is used to maintain a high flow rate of EW supply. Therefore, it is important to determine the EW stability (AcEW and AlEW) during storage. As shown in Figure 2 (a), the $\mathrm{pH}$ of AcEW remained stable during the seven days of storage. Maintaining the acidic $\mathrm{pH}$ is very important to ensure that the AcEW can be used as acidic cycle chemicals. Acidic chemicals such as acetic acid and phosphoric acid are commonly used for dairy cleaning (Watkinson, 2008). Acids are generally used to remove mineral scales such as hard water and millstones scales. While the ORP as shown in Figure 2 (b) maintains at a plateau for the first 5 days of storage. After 5 days, the AcEW shows a decreasing profile. Both $\mathrm{pH}$ and ORP are important properties to maintain as these properties contribute to AcEW antimicrobial properties. The high ORP (Kim et al., 2000; Liao et al., 2007; Huang et al., 2008), low pH (McPherson, 1993; Huang et al., 2008), chlorine content (Park et al., 2004; Liu, Duan and Su, 2006; Huang et al., 2008) and hydrogen peroxide content (Rico et al., 2007) are important chemical characteristics that contribute to antimicrobial properties of AcEW. Since aerobic and anaerobic bacteria can grow optimally at an ORP range of +200 to $800 \mathrm{mV}$ and -700 to +200 $\mathrm{mV}$, respectively. Thus, our target is to maintain our AcEW more than $800 \mathrm{mV}$. At higher ORP, the metabolic fluxes and ATP production of bacteria are modified (Huang et al., 2008). The pH ranging from 4 to 9 is optimal growth for bacteria. Our target is to maintain our AcEW to be lower than the $\mathrm{pH}$ of 4 .

During the 4 days of storage, the free and total chlorine content maintained at $10 \mathrm{mg} / \mathrm{L}$ (Figure 2 (c) and Figure (d) respectively). After 4 days, the total and free chlorine were found to be reduced gradually. However, 


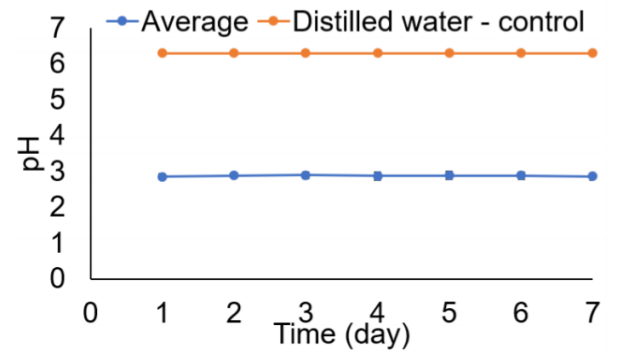

(a)

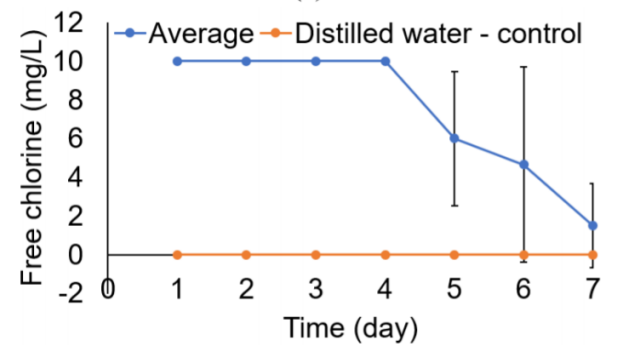

(c)

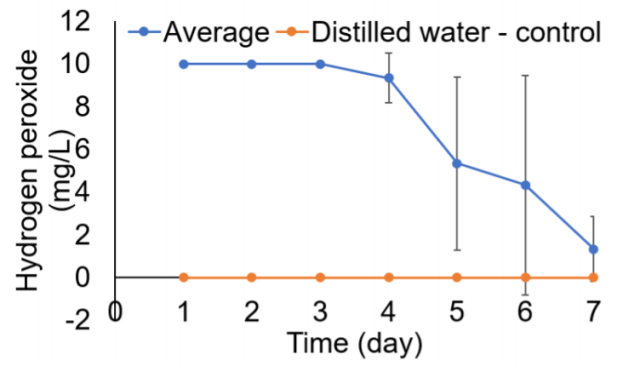

(e)

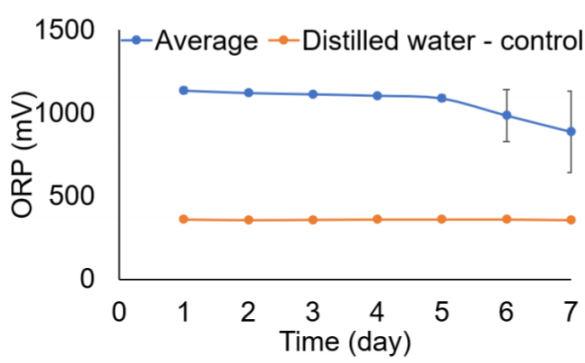

(b)

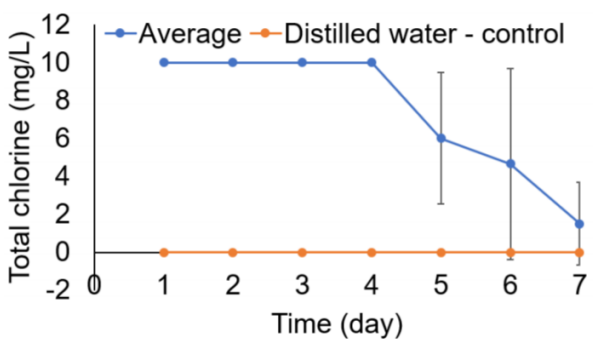

(d)

Figure 2. Effect of storage on the chemical and physical properties of the AcEW: a) pH, b) ORP, c) free chlorine, d) total chlorine and e) hydrogen peroxide.

the reduction rate was inconsistent for each repetition (large error bar). Large error bar indicates the large standard deviation. This might happen because the exposure to the atmosphere during daily measurement might reduce the total and free chlorine content. Every day, the bottle was opened for approximately 5 mins for physical properties measurements. When measurement time took less than 5 mins, the bottles were closed immediately. However, if the measurement time was delayed, the time the AcEW bottles were opened can be more than 5 mins. This mostly happens because the ORP meter takes some time to reach its accurate values. Thus, the exposure to the atmosphere might reduce the chlorine content inside AcEW. On day 7, there was almost no chlorine available in the AcEW. At lower $\mathrm{pH}$ of 2.3 to 2.7 , the outer membrane of bacteria will break down, allowing hypochlorous acid $(\mathrm{HOCl})$ to enter the inner membrane of the bacteria (Huang et al., 2008). $\mathrm{HOCl}$ is one of the most active compounds in chlorine compound. $\mathrm{HOCl}$ is highly oxidative and can deactivate the foodborne pathogens. $\mathrm{HOCl}$ reacts with DNA, induces the DNA-protein interactions, produces pyrimidine oxidation products and adds chloride to DNA bases (Birben et al., 2012). Thus, it is very important to maintain the chlorine content in AcEW.
Figure 2 (e) shows the properties of hydrogen peroxide during the 7 days of storage. The decrement pattern for $\mathrm{H}_{2} \mathrm{O}_{2}$ properties is similar to free and total chlorine (Figure 2 (c) and Figure 2 (d) respectively). The $\mathrm{H}_{2} \mathrm{O}_{2}$ maintained at $10 \mathrm{mg} / \mathrm{L}$ until day 3 and after that, the $\mathrm{H}_{2} \mathrm{O}_{2}$ level decreased drastically. On day 7 , there were 0,4 and $1 \mathrm{mg} / \mathrm{L} \mathrm{H}_{2} \mathrm{O}_{2}$ (1st, 2nd and $3 \mathrm{rd}$ repetition, respectively) that were detected in AcEW. Thus, it is very important to minimize the opening time of the bottles during storage. These results have proven that AcEW can be used as a good cleaner (acidic cycle chemicals) and disinfectant chemical as well. Hydrogen peroxide $\left(\mathrm{H}_{2} \mathrm{O}_{2}\right)$ has a strong detaching ability and kills bacteria without causing corrosion (Stanga, 2010). $\mathrm{H}_{2} \mathrm{O}_{2}$ also does not generate off-odours typical chlorine derivatives such as chlorophenols and chloramines (Stanga, 2010). None of the prior studies has reported the effect of $\mathrm{H}_{2} \mathrm{O}_{2}$ content in AcEW. The small size of $\mathrm{H}_{2} \mathrm{O}_{2}$ enables it to clean the membrane effectively as it can pass through small filtration membranes and enhances the biofilm removal and disinfection process (Stanga, 2010). By considering the $\mathrm{pH}, \mathrm{ORP}$, chlorine content and hydrogen peroxide content, the AcEW was at its best performance for 3 days.

\subsection{Storage of alkaline electrolyzed water}




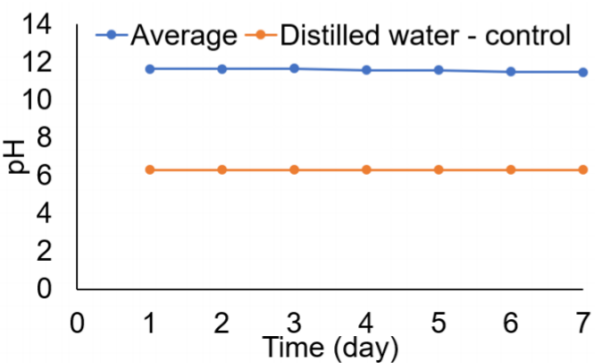

(a)

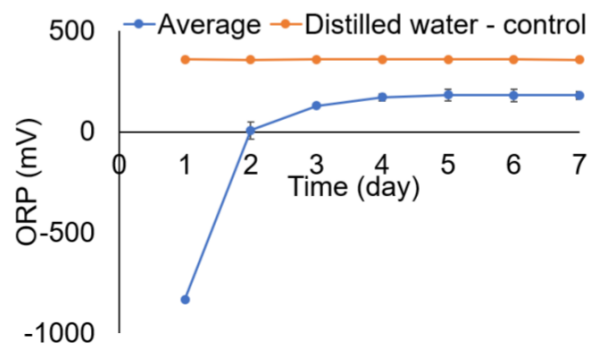

(b)

Figure 3. Effect of storage on the chemical and physical properties of a) $\mathrm{pH}$ and b) ORP of the AlEW.

Figure 3 shows the properties (pH, ORP) of AlEW during the 7 days of storage. Studies on storage of AlEW have not been well conducted as compared to AcEW (; Hsu and Kao, 2004; Ciu et al., 2009; Hsu et al., 2015) as most literature were focusing on the chlorine changes after storage time. Storage might affect the cleaning or removal performance of AlEW. The AlEW contains $\mathrm{NaOH}$ which is one of the detergent components used widely for cleaning food equipment surfaces (Walton, 2008; Khalid et al., 2016). The AlEW has the ability to act as $\mathrm{NaOH}$ and functions well in cleaning food processing equipment (Wang et al., 2016). The AlEW has been used to replace the alkaline wash in works by Dev et al. (2014) and Wang et al. (2016). AlEW has shown to give the same effect as $\mathrm{NaOH}$ during the alkaline wash. Alkaline detergent is good in removing organic soil (fat, protein and carbohydrate). When the fouling deposit is in contact with AlEW, the fouling deposit swell. The removal is easier after the swelling stage (Wang et al., 2016). The cohesive strength between the fouling deposits itself will be lesser and the adhesive strength between the surface and fouling deposit reduces (Liu et al., 2006; Law et al., 2009; Ho et al., 2010), thus, enabling the removal of fouling deposit. The alkaline cleaning step is important to ensure the removal of physical deposit. The remaining fouling deposit might act as a barrier and reduce the disinfection agent performance at the later stage of the disinfection process.

Most cleaning chemicals are alkaline in nature. The cleaning removal action (saponification, chelation and dispersion of fouling deposit) occurs effectively at an alkaline $\mathrm{pH}$ level. Moreover, alkaline performs best when soil can be hydrolyzed or saponified especially for fat-based fouling deposit such as grease, oils and fats. In this work, the efficiency of AlEW depends on the $\mathrm{pH}$ and ORP. Figure 3 shows that the $\mathrm{pH}$ of AlEW was stable during 7 days of storage.

Aerobic and anaerobic bacteria can grow optimally at the ORP range of +200 to $800 \mathrm{mV}$ and -700 to +200 $\mathrm{mV}$, respectively. At lower ORP $(<-700 \mathrm{mV})$, the metabolic fluxes and ATP production of bacteria can be modified, which eventually kills the bacteria (Kim et al., 2000; Liao et al., 2007; Huang et al., 2008). Lower ORP
$(<-700 \mathrm{mV})$ is non-ideal for microbes' growth. However, the ORP increased drastically between day 1 and 2 . On the first day, the ORP was $-829 \mathrm{mV},-831 \mathrm{mV}$ and -837 $\mathrm{mV}$ (1st, 2nd and 3rd repetition, respectively). The ORP reduced to $54 \mathrm{mV},-8 \mathrm{mV}$ and $-25 \mathrm{mV}$ (1st, 2nd and 3rd repetition, respectively). After that, the ORP of AlEW reached a plateau after day 3. On day 7, the ORP of AlEW were $162 \mathrm{mV}, 180 \mathrm{mV}$ and $202 \mathrm{mV}$ (1st, 2nd and 3rd repetition, respectively). Thus, the results have shown that AlEW can be used as alkaline cycle chemicals and disinfectants chemicals. The ORP properties of AlEW are the only antimicrobial properties which reduced drastically during storage. However, since the $\mathrm{pH}$ was still high, AlEW can still be effectively used as a disinfection chemical.

\section{Conclusion}

Green cleaners and disinfection deliver environmental benefits and at the same time can create operational cleaning efficiencies which highly benefit the SMEs manufacturers. This paper aimed to identify the potential of EW as green cleaner and disinfectant in SMEs food industry. Based on the impromptu interview with the workers, SME is facing difficulties to implement good cleaning and sanitation process due to the difficulty in selecting cleaning and disinfection chemical, limited knowledge in cleaning and disinfection process, budget constraints and limited storage area. SME manufacturers are facing difficulties to select suitable cleaning and disinfection detergent which suits them in terms of operational cost and storage area. Previous studies on EW show its potential as a green cleaner as it can be generated on-site, takes up less storage area, cheap and does not require wastewater treatment. In this study, the effect of storage duration on chemical properties of AcEW and AlEW was studied for 7 days. The chemical properties of EW will be reduced as time increased. It is a common practice to use fresh EW immediately after electrolysis to ensure the chemical properties $(\mathrm{pH}, \mathrm{ORP}$, free chlorine, total chlorine and hydrogen peroxide content) of EW are at its maximum. However, the common design of EW generator has a storage tank for EW. The tank is used to maintain a high flow rate of EW supply during the sanitation process. 
Hence, it is important to identify the stability of AlEW and AcEW during storage. In this work, the AcEW can be stored for 3 days while maintaining all its original properties $(\mathrm{pH}, \mathrm{ORP}$, free chlorine, total chlorine and hydrogen peroxide content). AlEW can be stored for 7 days as its $\mathrm{pH}$ showed no changes during the 7 days of storage. In order to maintain the physical properties of EW, food manufacturers must tightly close the EW bottles and keep it in a dark bottle to avoid exposure to the atmosphere. The results obtained from this work can be used as a guideline for SMEs to apply and store the EW reasonably. For future work, interviews with several food SMEs companies on the acceptance of EW as sanitation solution alternatives should be done.

\section{Conflicts of interest}

The authors have declared no conflict of interest.

\section{Acknowledgement}

The authors would like to acknowledge the financial support provided by Universiti Putra Malaysia (9548500) Putra IPS grant.

\section{References}

Al-Haq, M.I., Sugiyama, J. and Isobe, S. (2005). Applications of Electrolyzed Water in Agriculture and Food Industries. Food Science and Technology Research, 11(2), 135-150. https://doi.org/10.3136/ fstr.11.135

Ayebah, B. and Hung, Y.C. (2005). Electrolyzed water and its corrosiveness on various surface materials commonly found in food processing facilities. Journal of Food Process Engineering, 28(3), 247264. https://doi.org/https://doi.org/10.1111/j.17454530.2005.00424.x

Birben, E., Sahiner, U.M., Sackesen, C., Erzurum, S. and Katayci, O. (2012). Oxidative stress and antioxidant defense. World Allergy Organization Journal, 5(1), 9 -19 .

\section{WOX.0b013e3182439613}

Colangelo, M.A., Caruso, M.C., Favati, F., Scarpa, T., Condelli, N. and Galgano, F., (2015). Electrolysed water in the food industry as supporting of environmental sustainability. In Vastola, A. (Ed.). The Sustainability of Agro-food and Natural Resource Systems in the Mediterranean Basin, p. 385-397. Verona, Italy: Springer Link. https:// doi.org/10.1007/978-3-319-16357-4

Cui, X. Shang, Y., Shi, Z., Xin, H. and Cao, W. (2009). Physicochemical properties and bactericidal efficiency of neutral and acidic electrolyzed water under different storage conditions. Journal of Food Engineering, 91(4), 582-586. https:// doi.org/10.1016/j.jfoodeng.2008.10.006

Dev, R.S.S., Demirci, A., Robert, E.G. and Puri, V.M. (2014). Optimization and modeling of an electrolyzed oxidizing water based Clean-In-Place technique for farm milking systems using a pilotscale milking system. Journal of Food Engineering, 135, 1-10. https://doi.org/10.1016/ j.jfoodeng.2014.02.019

Etienne, G. (2006). Principles of Cleaning and Sanitation in the Food and Beverage Industry. USA: iUniverse.

Fabrizio, K.A. and Cutter, C.N. (2004). Comparison of electrolyzed oxidizing water with other antimicrobial interventions to reduce pathogens on fresh pork. Meat Science, 68(3), 463-468. https:// doi.org/10.1016/j.meatsci.2004.04.013

Gil, M.I., Selma, M.V., López-Gálvez, F. and Allende, A. (2009). Fresh-cut product sanitation and wash water disinfection: Problems and solutions. International Journal of Food Microbiology, 134(12), 37-45. https://doi.org/https://doi.org/10.1016/ j.ijfoodmicro.2009.05.021

Guzel-Seydim, Z.B., Greene, A.K. and Seydim, A.C. (2004). Use of ozone in the food industry. LWT Food Science and Technology, 37(4), 453-460. https://doi.org/10.1016/j.lwt.2003.10.014

Hasnan, N.Z.N., Ab Aziz, N., Taip, F.S. and Zulkifli, N. (2019). Spine layout design for improving food hygiene and reducing travelled distances in a smallscale burger patties processing. Food Research, 3(4), 295-304. https://doi.org/10.26656/fr.2017.3(4).149

Heinz, G. and Hautzinger, P. (2007). Meat processing technology: For small to medium scale producers. Bangkok, Thailand: Food and Agriculture Organization of the United Nations Regional Office for Asia and the Pacific, Bangkok, Thailand.

Ho, A.L., Tan, V.C., Ab. Aziz, N., Taip, F.S. and Ibrahim, M.N. (2010). Pink Guava Juice Pasteurisation: Fouling Deposit and cleaning studies. Journal - The Institution of Engineers, Malaysia, 71 (4), 50-62.

Hsu, S.Y. and Kao, H.Y. (2004). Effects of storage conditions on chemical and physical properties of electrolyzed oxidizing water. Journal of Food Engineering, 65(3), 465-471. https:// doi.org/10.1016/j.jfoodeng.2004.02.009

Hsu, G.S.W., Hsia, C.W. and Hsu, S.Y. (2015). Effects of process conditions on chlorine generation and storage stability of electrolyzed deep ocean water. Journal of Food and Drug Analysis, 23(4), 735-741. https://doi.org/10.1016/j.jfda.2015.05.002 
Huang, Y.R., Hung, Y.C., Hsu, S.Y., Huang, Y.W. and Hwang, D.F. (2008). Application of electrolyzed water in the food industry. Food Control, 19(4), 329345. https://doi.org/10.1016/j.foodcont.2007.08.012

Hui, Y.H. (Ed.) (2012). Sanitation of Food-Processing Equipment. In Handbook of Meat and Meat Processing, p. 903-915. $2^{\text {nd }}$ ed. Boca Raton, Florida: CRC Press. https://doi.org/10.1201/b11479

Khalid, N.I., Ab Aziz, N., Thani, N.M., Shapi'i, R. and Rahman, N.F.A. (2020). Electrolyzed water as a sustainable cleaning and disinfection chemical for SMEs Malaysian meat processing food industries: Challenges and uncertainties. Journal of Agricultural Food Engineering, 1(1), 0006. https://doi.org/http:// doi.org/10.37865/jafe.2020.0006

Khalid, N.I. Sulaiman, N.S., Ab Aziz, N., Taip, F.S., Sobri, S. and Nor-Khaizura, M.A.R. (2020). Optimization of Electrolysis Parameters for Green Sanitation Chemicals Production Using Response Surface Methodology. Processes, 8(7), 792. https:// doi.org/https://doi.org/10.3390/pr8070792

Khalid, N.I., Saulaiman, U.S., Nasiruddin, N.A., Hatdran, M.M., Ab Aziz, N., Nor Khaizura, M.A.R., Hasnan, N.Z.N., Taip, F.S. and Sobri, S. (2019). Integrating cleaning studies with industrial practice: Case study of an effective cleaning program for a frozen meat patties SME factory. Journal of Cleaner Production, 235, 688-700. https://doi.org/10.1016/ j.jclepro.2019.06.317

Khalid, N.I. and Ab Aziz, N. (2019). Challenges in cleaning for frozen food SMEs: Current and suggested cleaning program presented at the Konvensyen Kebangsaan Kejuruteraan Pertanian Dan Makanan 2019, Putrajaya, 21st March 2019, p. 86-90. Putrajaya, Malaysia: Kementerian Pertanian dan Industri Asas Tani.

Khalid, N.I., Sulaiman, S., Ab Aziz, N., Taip, F.S., Sobri, S. and Nor-Khaizura, M.A.R. (2018). Electrolyzed water as a green cleaner: chemical and physical characterization at different electrolysing parameters. Food Research, 2(6), 512-519. https:// doi.org/10.26656/fr.2017.2(6).107

Khalid, N.I., Nordin, N., Chia, Z.Y., Ab Aziz, N., Nuraini, A.A, Taip, F.S. and Ahmedov, A., (2016). A removal kinetics approach for evaluation of economic cleaning protocols for pink guava puree fouling deposit. Journal of Cleaner Production, 135, 1317-1326. j.jclepro.2016.06.095

Kim, C., Hung, Y.C. and Brackett A.E. (2000). Roles of Oxidation-Reduction Potential in Electrolyzed Oxidizing and Chemically Modified Water for the Inactivation of Food-Related Pathogens. Journal of
Food Protection, 63(1), 19-24. https:// doi.org/10.4315/0362-028x-63.1.19

Law, H.Y., Ong, C.I., Ab. Aziz, N., Taip, F.S. and Muda, N. (2009). Preliminary Work on Coconut Milk Fouling Deposits Study. International Journal of Engineering and Technology IJET-IJENS, 9(10), 813.

Liao, L.B., Chen, W.M. and Xiao, X.M. (2007). The generation and inactivation mechanism of oxidationreduction potential of electrolyzed oxidizing water. Journal of Food Engineering, 78(4), 1326-1332. https://doi.org/10.1016/j.jfoodeng.2006.01.004

Liu, W., Fryer, P.J., Zhang, Z., Zhao, Q. and Liu, Y. (2006). Identification of cohesive and adhesive effects in the cleaning of food fouling deposits. Innovative Food Science and Emerging Technologies, 7(4), 263-269. https://doi.org/10.1016/ j.ifset.2006.02.006

Liu, C., Duan, J. and Su, Y.C. (2006). Effects of electrolyzed oxidizing water on reducing Listeria monocytogenes contamination on seafood processing surfaces. International Journal of Food Microbiology, 106(3), 248- 253. https:// doi.org/10.1016/j.ijfoodmicro.2005.06.020

McPherson, L.L. (1993). Understanding ORP's in the disinfection process. Water Engineering and Management, 140, 29-31.

Meireles, A., Giaouris, E. and Simões, M. (2016). Alternative disinfection methods to chlorine for use in the fresh-cut industry. Food Research International, 82, 71-85. https://doi.org /10.1016/ j.foodres.2016.01.021

Ozer, N.P. and Demirci, A. (2006). Electrolyzed oxidizing water treatment for decontamination of raw salmon inoculated with Escherichia coli O157: H7 and Listeria monocytogenes Scott A and response surface modeling, Journal of Food Engineering, 72(3), 234-241. https:// doi.org/10.1016/j.jfoodeng.2004.11.038

Park, H., Hung, Y.C. and Chung, D. (2004). Effects of chlorine and $\mathrm{pH}$ on efficacy of electrolyzed water for inactivating Escherichia coli O157:H7 and Listeria monocytogenes. International Journal of Food Microbiology, 91(1), 13- 18. https://doi.org/10.1016/ S0168-1605(03)00334-9

Rahman, S.M.E., Khan, I. and Oh, D.H. (2016). Electrolyzed Water as a Novel Sanitizer in the Food Industry: Current Trends and Future Perspectives. Comprehensive Reviews in Food Science and Food Safety, 15(3), 471-490. https://doi.org/10.1111/15414337.12200

Rico, D., Martin-Diana, A.B., Barat, J. and Barry-Ryan, 
C. (2007). Extending and measuring the quality of fresh-cut fruit and vegetables: A review. Trends in Food Science and Technology, 18(7), 373-386. https://doi.org/10.1016/j.tifs.2007.03.011

Rood, L., Koutoulisa, A., Bowman, J.P., Evans, D.E., Stanley, R.A. and Kaur, M. (2018). Control of microbes on barley grains using peroxyacetic acid and electrolyzed water as antimicrobial agents. Food Microbiology, 76, 103-109. https://doi.org/10.1016/ j.fm.2018.05.002

Shirota, K. and Isaka, A. (2001). U.S. Patent No. 6,294,073 B1. Washington, DC: U.S. Patent and Trademark Office.

Stanga, M. (2010). Sanitation: Cleaning and Disinfection in the Food Industry. Weinheim: Wiley-VCH. https://doi.org/10.1002/9783527629459

Tetra Pak. (2015) Cleaning in place - A guide to cleaning technology in the food processing industry, p. 40. Lund, Sweden: Tetra Pak International S.A.

Venkitanarayanan, K.S., Ezeike, G.O., Hung, Y.C. and Doyle, A.P. (1999). Efficacy of Electrolyzed Oxidizing Water for Inactivating Escherichia coli O157:H7, Salmonella enteritidis and Listeria monocytogenes. Applied and Environmental Microbiology, 65(9), 4276-4279. https:// doi.org/10.1128/AEM.65.9.4276-4279.1999

Walton, M. (2008). Principles of cleaning-in-place (CIP). In Tamime A.Y. (Ed). Cleaning in Place: Dairy, Food and Beverages Operation, p. 1-9. $3^{\text {rd }}$ ed. Oxford, United Kingdom: Blackwell Publishing. https://doi.org/10.1002/9781444302240

Watkinson, W.J. (2008). Chemistry of Detergents and Disinfectants. In Tamime A.Y. (Ed). Cleaning in Place: Dairy, Food and Beverages Operation, p. 5680. $3^{\text {rd }}$ ed. Oxford, United Kingdom: Blackwell Publishing. https://doi.org/10.1002/9781444302240

Wang, X., Puri, V.M., Demirci, A. and Graves, R.E. (2016). Mathematical modeling and cycle time reduction of deposit removal from stainless steel pipeline during cleaning-in-place of milking system with electrolyzed oxidizing water. Journal of Food Engineering, 170, 144-159. https://doi.org/10.1016/ j.jfoodeng.2015.09.027 